DE DE GRUYTER

OPEN
Journal of Intercultural Management

Vol. 7, No. 3, September 2015, pp. 69-99

DOI 10.1515/joim-2015-0022

Sami Basly ${ }^{11}$

University of Paris West Nanterre La Défense, Nanterre - France

\title{
Family Involvement in the Firm and Exports in the Family SME: Is the Manager's International Orientation Influential?
}

\begin{abstract}
Does the family involvement affect exports in the family firm? The literature seems to support this view even if the direction and magnitude of this impact remains controversial. Drawing on the perspectives of agency [Chrisman et al. 2004; Schulze et al. 2001] and stewardship as applied to family firms [Davis, Schoorman and Donaldson 1997] and also on socio-emotional wealth perspective [Gómez-Mejía et al. 2007], this study seeks to contribute to this debate by studying the influence of family involvement on the SME exports intensity. To reconcile the divergent views, our research attempts to assess the role of the manager's international orientation as a variable moderating the relationship between family involvement and exports in SMEs. Based on a hypotheticaldeductive approach, the study uses a sample data of 125 family SMEs obtained through a questionnaire. The results show that even if the positive influence of the manager's international orientation is corroborated, its moderating role seems to be limited to only one facet of the construct of family involvement i.e. involvement in management. Moreover, owning-family involvement in management seems to negatively influence exports while some results argue for a positive effect of the family involvement in ownership on exports.
\end{abstract}

Key words: family business, internationalization, exporting, family involvement, international orientation.

\section{Introduction}

The internationalization of activities through exports illustrates the dilemma that owners and managers of family businesses can meet as for firm's growth. As it is

${ }^{11}$ sbasly@u-paris10.fr 
more risky than national or local growth, internationalization is both feared because it entails a risk of loss of control, but also sought since it is an important vehicle for business development and value creation. Given its ambivalent characteristics (both owner and manager), the owning-family in a family SME would be in continuous search of balance between the pursuit of growth through the implementation of risky investments and risk aversion in order to protect the heritage to perpetuate. While not explicitly focusing on SMEs, the issue of internationalization in family businesses has been the subject of a lot of research leading generally to nonconcordant results [Gallo and Estapé 1992; Luostarinen and Gallo 1992; Sharma et al. 1997; Gallo and Pont 1996; Miller et al. 2003]. While some emphasize the virtues of family involvement in the business, others doubt the contribution of the family entity and point out its inefficiencies which are explained particularly by the dominance of emotions and probable non-rational decisions.

Drawing on the perspectives of agency [Chrisman et al. 2004; Schulze et al. 2001] and stewardship as applied to family firms [Davis, Schoorman and Donaldson 1997] and also on socio-emotional wealth perspective [Gómez-Mejía et al. 2007], this study seeks to contribute to this debate by studying the influence of family involvement on the SME exports intensity. Indeed, agency preaches the lack of conflict of interest within family firms even if, in certain situations, the owning-family is likely to impose its views and choices of governance on minority shareholders which lead to agency costs [Chrisman et al. 2004; Schulze et al. 2001]. Besides, while the stewardship theory argues for cohesion and altruism, family firms are not free from conflicts as a family is not a monolithic or homogeneous group of people with congruent interests [Davis, Schoorman and Donaldson 1997]. Besides, excessive altruism can also lead to a different type of agency costs. In addition to these agency costs, the preservation of socio-emotional wealth is purported to affect internationalization [Gomez-Mejia et al. 2010] as it may have greater priority over economic objectives [Sanchez-Bueno and Usero 2014]. SEW includes factors such as the desire to perpetuate family values and the retention of a strong family identity, the preservation of the founder's legacy, or the continuation of the family dynasty [Gomez-Mejia et al. 2007]. These non-economic factors are distinguishing features of family firms that may affect the scope of their businesses [Sanchez-Bueno and Usero 2014]. These three theoretical lenses (agency, stewardship, SEW) are useful to understand the motives and hindrances of the family firm internationalization.

A family business is controlled by one or more families who are involved in the governance or management and have an equity interest in the organization. Although it is necessary to hold a majority of the voting rights or influence related to patrimonial involvement in order to influence strategic decision making, it is not necessary to ensure a strong patrimonial involvement i.e. the ownership of the majority of equity in order to hold power within the firm. For the purposes of 
the empirical research which will be discussed in the context of this study, we will waive slightly of the previous theoretical position in order to constitute a sample of family SMEs. Not only will the criterion of influence be appreciated but also the perception that managers have about their businesses.

While it is recognized that family involvement would have a positive or negative effect on internationalization, and in particular on exports, it seems that the intensity and direction of these effects could be understood by taking into account contextual, contingent or moderator variables. Our research aims to make a contribution by analyzing the moderating role that international orientation of the family business manager could exert on the relationship between family involvement and exports. While this manager's attribute is a well-documented construct in international business research, different approaches like SMEs internationalization [Reuber and Fisher 1997; Lloyd-Reason and Mughan 2000], multinationalization [Perlmutter 1969], learning-based models of internationalization [Johanson and Vahlne 1977] or international entrepreneurship [McDougall, Sane and Oviatt 1994] have used different terminology (eg. "international orientation", "global mindset", "transnational mentality", "multinational mindset") but substantively examine the same phenomenon [Levy et al. 2007]. Following Levy et al. [2007], we are focusing on the "cultural perspective" of this construct which suggests that the answer to managing the challenges induced by globalization is to move away from an ethnocentric mindset and develop a global mindset - a mindset that involves cultural self-awareness, openness to and understanding of other cultures, and selective incorporation of foreign values and practices Levy et al. $[2007]^{12}$. While we espouse this perspective, we will privilege the use of the term of "international orientation" at the detriment of "global mindset" as we exclude in our theory setting and empirical study multinationals or global firms which already gained a substantial internationalization level and focus on internationalizing family SMEs that require like other types of SMEs critical resources in order to open to and succeed in foreign markets. In that, manager's international orientation would be a prerequisite for that the internationalization process could start and progress. We choose also to exclude the international entrepreneurship perspective whose scholars assume that the global mindset is characteristic of born global firms [Oviatt and McDougall 1994]. As our focus is on family firms and known that being a family firm require not only the control of votes and involvement in governance but also a relative sustainability which could be demonstrated through generational succession, we conceive that a born global firm could be hardly qualified as a family firm from its inception.

In a hypothetical-deductive approach, our study is based on a sample data of 125 family businesses which responses were obtained through a questionnaire. A set of

12 These authors advance also a strategic perspective focusing on aspects of environmental complexity and strategic variety stemming from globalization. 
hypotheses is derived from the literature and tested through ten TOBIT regression models. Overall, three of the six hypotheses find empirical support. In fact, if the positive influence of the international orientation on exports is corroborated, its moderator role seems to be limited to only one facet of the construct of family involvement namely involvement in management. Moreover, owning-family involvement in management seems to negatively affect exports while some results argue for a favorable effect of the involvement in ownership on exports.

The article is structured in two parts. The first presents the research theoretical framework, justifies the study variables and hypotheses. The second presents the empirical study: it describes the data, presents the methodology and results then interprets the results, presents their implications and suggests avenues for future research.

\section{Conceptual framework and hypotheses development}

\section{The involvement of the family in the business}

The concept of family involvement has been exploited in the context of a dominant theoretical approach aimed to characterize the family firm. According to Harvey [1999], the deep involvement of owner-managers in the business is a hallmark of the family firm. In their effort to define and characterize the family firm, Astrachan et al. [2002] argue that it is not appropriate to categorize firms into family and non-family ones but it is more relevant to assess the degree and manner by which the family is involved in the business and affects its operations. The family involvement in the firm influences strategic decision-making in two ways: the involvement in the control of the firm through the ownership of equity and/or voting rights; and the involvement in the running of the business both through management and governance.

Overall, there is controversy in the literature about the impact of family involvement on the internationalization of the firm, and particularly on the intensity of exports. For some authors, the family business is weakly internationalized because of its very nature and particularly its commitment to the local culture and environment [Gallo and Estapé 1992]. All things being equal, family firms would be more conservative and resistant than non-family firms with respect to changes whose consequences could jeopardize their survival [Jenster and Malone 1991]. Thus, for Segaro et al. [2014], the family culture of commitment is likely to reduce the degree of internationalization of family SMEs. Moreover, investing the majority of its wealth in the business and relying on it to satisfy its financial needs, the owningfamily may fear internationalization because of financial risks that could affect the firm existence. Besides, this strategic option is a decision that could trigger conflicts among family members. In particular, shareholder disputes can paralyze the 
entrepreneurial process abroad from identifying internationalization opportunities to choices on how to exploit these opportunities, which inhibit internationalization [Sciascia et al. 2010]. More generally, the common divergence that may exist between financial and non-financial goals or between corporate goals and family goals could imply conflicts concerning the need to internationalize the business [Zahra 2003]. Disagreements between family members may also arise about the opportunity, scope, pace of internationalization or entry modes to be adopted [Zahra 2003]. Internationalization is usually accompanied by a decrease in short-term profits in favor of an uncertain future profitability [Gallo and Luostarinen 1991]. Moreover, this strategy would be avoided because, a priori, it may deteriorate the quality of staff employed, values and organizational culture [Zahra 2003]. In addition, it is not excluded that the internationalization could be a strategy of the family business manager pursuing its own interests over those of the family [Zahra 2003]. Finally, the literature highlights the low control and access to resources including financial ones exhibited by family businesses especially when they are of small or medium size [Gallo and Estapé 1992; Luostarinen and Hellmann 1995; Sciascia et al. 2010].

In contrast, for other authors [Simon 1996, Wang 2010; Chen 2011; Carr and Bateman 2009], because adopting a long-term perspective, the family firm is likely to promote investments which benefits are remote and would be devoted therefore more easily to a strategy of internationalization.

The contradiction of these approaches leads us to distinguish two facets of family involvement and to study their impact on the export activity individually and then jointly. Although they are generally associated in family businesses, it is not uncommon to find, on one hand, professionalized family firms where family managerial involvement is weak and, on the other hand, others whose reins are held by members of a family despite weak equity ownership.

\section{Family involvement in ownership}

In general, the ownership structure of the firm would have a significant influence on strategic decision making and resulting strategic choices and behaviors [Zahra 1996]. Ownership control should align firm's and owners interests and encourages owner-managers to pursue risky activities such as internationalization. Moreover, it allows aligning managerial decision making and owners' interests [Katz and Niehoff 1989]. Unlike a configuration in which managers are relatively free as for the firm's strategy, they would behave differently and take different decisions when owners are actively involved in the firm. If research about the relationship between ownership control of the family firm and internationalization is very rich, it delivers inconsistent results. In a first set of research, family firms are described as being weakly internationalized [Donckels and Frohlich 1991; Luostarinen and Hellman 1995, Simoes and Crespo 2002], export less than non-family firms [Donckels and Frohlich 1991] and when they go international will be entering a smaller number 
of foreign countries [Zahra, 2003]. A study by Dosoglu-Guner [2001] attempts to show that ownership structure and export intention are strongly associated and that owner-controlled firms are reluctant to export because owners favor rapid returns on investment while exportation is rather a lengthy process whose fruits are harvested on the long run. Fernandez and Nieto [2006] support this analysis in the case of family firms as they observe that export intensity is negatively related to the extent of family ownership. In a study about foreign investment behavior of Indian firms from the automotive and pharmaceutical sectors, Bhaumik et al. [2007] find that the share of equity owned by the family has a negative effect on foreign direct investment.

If this position is supported by a number of studies, the stewardship approach challenges this view and show that family firms intrinsically comprehend many factors promoting its internationalization [eg. Wang 2010; Chen 2011]. Active research and adoption of an internationalization strategy would be an expression of the goal of maximizing the family wealth. Indeed, according to the teachings of the agency theory, the family, as the firm's owner, should be favorable to risk taking because it benefits solely from generated gains while risk of failure is also supported by creditors. In a stewardship approach, Zahra [2003] observes that if internationalization is necessary to ensure future performance of the firm, the manager will implement it even if the perceived risks are high. The shared vision and comprehension of the firm's mission developed by family members provides support to the manager by reducing the risks associated with long-term strategic options such as internationalization [James 1999]. Altruism enshrined in these firms allows family shareholders to allocate resources to the protection and development of their investment [Zahra 2003] while owner-manager may act as a steward of these resources. Consequently, family control of the ownership ensures that managers can deploy necessary resources to achieve this strategy. In addition, family firms can mobilize their reputation and social capital including long-term relationships with different partners and also with other family enterprises established abroad [Okoroafo 1999] to reduce entry barriers and position their selves favorably in foreign markets. Finally, the relative stability of family ownership should imply a weak turn-over of managers whose future is bound to the firm and who may accordingly analyze the internationalization strategy more rationally. Besides, the possible reluctance of the owning-family about this strategy and also the perceived risks may decrease. Supporting this assumption, Carr and Bateman [2009] found that the international configurations of the largest world's family firms are associated in the long term with a better performance (ROI). Other studies found that the percentage of equity held by the family is positively correlated with the degree of internationalization [Zahra 2003; Chen 2011] and geographic scope [Zahra 2003]. For Simon [1996], high performing family firms adopt a strong global orientation which allows them to achieve high foreign sales. 
Accordingly, our research formulates the following hypothesis:

H1a: The degree of family involvement in ownership positively influences export intensity.

\section{Family involvement in management}

Family involvement can take various forms [Zahra 2003]: some family members may be managers or directors or occupy certain operational management positions. Some studies have attempted to study the impact of this variable on internationalization [Zahra 2003; Abdellatif et al. 2010]. For example, Zahra [2003] observed that family involvement index is positively correlated to the degree of internationalization but negatively influences the number of penetrated markets [Zahra 2003]. Cerrato and Piva [2010] confirmed the existence of a negative relationship between family involvement in management and the decision to internationalize the SME. In the same vein, for Sciascia et al. [2010], this involvement negatively influences international entrepreneurship in family businesses. Overall, the results seem somewhat contradictory and if family members are the source of human, financial and social capital important for the family firm [Kim and Gao 2013] and also provide many resources and competences to the organization (commitment, loyalty, trust, specific expertise, capital and financial or physical assets), their role in corporate strategy and particularly in internationalization does not seem very clear.

According to agency theory, family involvement in corporate governance would be beneficial because of the natural alignment of interests between managers and owners about the growth opportunities and risk. Therefore, managers are more motivated not to behave in an opportunistic manner [Schulze et al. 2001]. Kinship moderates self-interest and conflicts that it may imply as it is reflected in the loyalty and commitment vis-à-vis the family and the business. For example, the need to monitor the behavior of an agent who is a member of the family is reduced because communication and cooperation are facilitated by familiarity and intimate knowledge. Zahra [2003] argues that if involvement in ownership allows the manager to deploy necessary resources to internationalization, involvement in management can be used to reduce managerial opportunism. By reducing informational asymmetries between the manager and the other family members, involvement allows family members not only to get the information they need to adhere to the internationalization strategy but also knowledge necessary to the evaluation of this strategy [Zahra 2003]. Moreover, managerial involvement of family members allows for the development of psychological ownership and improves the appraisal of challenges encountered by the firm and also its strengths, weaknesses, resources and competences [Zahra 2003]. This would be particularly true for internationalization. Therefore, altruism described by stewardship theory [Davis et al. 1997; Salvato 2002] can push owner-managers to internationalize their 
firms in order to perpetuate it, protect it and make it more legitimate and profitable for future generations.

The benefits of involvement in management as addressed by agency and stewardship theories are however mitigated in different ways. For example, Sharma et al. [1997] note that because of the family involvement, the goals and objectives of the family firm may deviate from the objective of firm value maximizing that managerial firms are devoted to. Indeed, if the goals of family firms are both financial and non-financial [Tagiuri and Davis 1992], they may also evolve depending on the interaction between the family and firm needs. Consequently, Chrisman, Chua and Litz [2004] argue that agency problems in family firms are more complex precisely because of the juxtaposition of economic and non-economic goals. For their part, Schulze et al. [2001, 2003] show that family management, despite its advantages, exposes the firm to an agency risk of a different nature. First, altruism entails a risk of adverse selection due to the effect of private ownership on the efficiency of the labor market. Indeed, the family business would tend to employ opportunistic or low competence agents as they want to promote shareholders to management positions [Salvato 2002]. In fact, as the preservation of SEW represents a key noneconomic reference point for decision making in family firms [Berrone et al. 2012], they may be inclined to make strategic choices that cannot be explained by applying an economic reference point. Moreover, as they feel less or no corporate control market discipline, owner-managers are likely to make decisions that may harm them and their family [Jensen 1994]. Over time, the economic incentive to maximize personal utility can blur the perception of the owner-manager of what is better for the firm and the family; He may confuse his personal interests with the interests of the firm and the family. For example, an aged manager can avoid undertaking investments that other family members encouraged because he perceives them as too risky or as they personally require him to develop new skills [Schulze et al. 2001].

In addition, a family owning and running a business is often not a monolithic or homogeneous group of people with converging interests. In fact, it is very common that conflicts of a more or less severe intensity may occur within the family. They may involve family members of the same generation or of different generations or also oppose family members to external employees [Gersick et al. 1997]. When occurring among family members occupying different roles in management and governance, conflicts create difficulties affecting collaboration and information sharing. Besides, altruistic behavior between family members can fade encouraging family members to work towards achieving their own goals at the expense of general family well-being [Schulze et al. 2001].

Finally, the literature emphasizes that family members' involvement in formal governing bodies, like the board of directors, may be only a formality. As the 
real strategic decisions would be taken in informal strategic areas, this body does not seem effective and its role would not have positive influence on family firms' strategy [Melin and Nordqvist 2000]. In particular, when it is dominated by the owning-family, its role seems even to be unfavorable to business development and implemented strategies. For example, the study of Mustakallio and Autio [2001] showed that family involvement in this monitoring body has a negative influence on the achievement of its missions. Calabro and Mussolino [2011] observe also the weakness of the board mission in family firms and advocate for the inclusion of outside directors in order to increase exports [Calabro and Mussolino 2011].

All these arguments lead us to believe that:

H2a: The degree of family involvement in management negatively influences export intensity.

\section{The interaction of involvement in ownership and management}

Few studies have differentiated the involvement in ownership and management as research have simply confused them or at best implicitly assumed a cumulative effect [Abdellatif et al. 2010; Sciascia et al. 2010]. For some authors, the interaction of these two areas of family involvement has a positive impact on internationalization. Zahra [2003] argues, for example, that involvement in ownership provides the manager with the power to internationalize the firm while involvement in management allows him to gain the knowledge and competences necessary to make strategic choices related to internationalization. Their combined effect would be beneficial and commit the firm to higher levels of internationalization.

However, many arguments among those mentioned above highlight the risks of entrenchment, opportunism, inaction or stagnation associated with the involvement of family members in management or monitoring bodies. Stewardship behavior of the manager and/or members of his family and the resulting altruism can be transformed into means of a non-rational management because emotions and the desire to take primarily into account the family members' needs may dominate. Thus, if the concentration of firm's ownership in the hands of a family would not in itself be against export activities as the arguments presented above tend overall to credit the hypothesis of a positive impact, involvement of the family in management could mitigate or even reverse this impact and create favorable conditions of an inward orientation or a strategic rigidity thus inhibiting export.

In light of these arguments, we believe that:

H3a: The interaction of the involvement in ownership and the involvement in management would have a negative impact on export intensity.

The diversity of results and even contradictions identified as for the influence of family involvement on firm's internationalization and particularly on exports was analyzed and justified by different theoretical approaches such as agency and stewardship. Taken together, these findings suggest that certain «conditions» or 
existing organizational circumstances in the family firm can promote a particular behavior of family members and firm's manager [Kim and Gao 2013]. It is probably useful to consider the internal contingencies that may moderate the relationship between family involvement and exports. Particularly, we believe that the manager's international orientation is a variable that can contribute to a better understanding of the intensity and direction of the relationship between family involvement and exports and may be useful to reconcile the divergent views.

\section{The manager's international orientation and the internationalization of the firm}

An important strand of literature on the determinants of exports in SMEs is concerned by the role of the manager in the different stages of the export process. By influencing firm interactions with the environment [Kelly et al. 2000], his characteristics and attributes are identified by numerous studies as factors that lead him to engage the firm in international activities. Many individual characteristics (such as experience, education, skills, and travels), attitudes and international perceptions (as for risk or costs and opportunities of international development) are then identified and validated by empirical studies. Among these determinants, international orientation is a well-studied variable in international business research [Reid 1981; Dichtl et al. 1990; Collinson and Houlden 2005; Acedo and Florin 2006; Belso-Martinez 2006; Acedo and Jones 2007; Ruzzier et al. 2007; Knight and Kim 2009]. For these authors, managers and entrepreneurs familiar with foreign markets through travel, language knowledge or through living experience abroad will have a more positive attitude towards considering international expansion as an opportunity for growth than those without such experience. For Belso-Martinez [2006], this international orientation leads to a proactive attitude by managers, which can become a dynamic element that minimizes and even eliminates some of the traditional stages established by the Scandinavian Model. Thanks to past international work experience or established personal networks and relationships abroad, managers would possess the skills necessary to conduct international business arrangements [Manolova et al. 2002]. For Knight and Kim [2009], international market orientation and international orientation seem to be the strongest indicators of International Business Competence (IBC). For these authors, international orientation has a wide scope of influence on SME business activities. That is, having a strong international orientation can shape organizational culture. The results of Miocevic and Grnjak-Karanovic [2011] suggest that cognitive capability i.e. global mindset and information-based capabilities are clear prerequisites for successful SME internationalization process. In the same vein, Moen and Servais [2002] found that early exporters scored more highly on global orientation measures than those who took longer to commence internationalization. Similarly, Acedo and Florin 
[2006] explain that the innovative behavior associated with international expansion of SMEs is caused primarily by the proactive personality of the entrepreneurs and their international orientation. These numerous studies show that the international orientation posture positively influences the firm's degree of internationalization and exports, in particular. Recently, Larimo [2013] lists 31 empirical studies examining the link between managers' international orientation and export activity. It appears from this literature review that 23 studies found a positive influence and none of them obtained a negative effect while 8 showed insignificant results. Therefore, it is generally admitted that this variable has a positive impact on exports.

If these studies focus on any type of firm without distinction, it is reasonable to expect that this positive impact should be observed for family SMEs. In his empirical study, Larimo [2013] supports this argument by observing that if the international orientation of family business managers is lower than that of nonfamily business managers, it still influences favorably exports intensity. This is to our knowledge the unique study to have studied the impact of this variable, among others, on exports in the case of family firms. It seems essential to focus on this variable and evaluate not only its influence on export intensity but more specifically the possible moderating role it may play as for the relationship between family involvement and export intensity. This orientation should act as a catalyst or accelerator of international business activities by minimizing the risks perceived by members of the owning-family and thus engaging the firm towards export.

If no research has been dedicated exclusively to the study of this variable, several studies in the field of family business evoke the notion of «family culture favorable to international development» [Swinth and Vinton 1993; Gallo and Pont 1996; Montemerlo and Corbetta 1995]. Without explicitly discussing the role of the manager, these studies emphasize the role of the family's international culture as a stimulant of the firm's motivation to acquire a substantial and stable international position [Corbetta and Montemerlo 1995]. Gallo and Sveen [1991] suggest that unless family businesses have "international predispositions", they would be reluctant to monitor global changes or integrate them into their domestic decisions. Thanks to its «stock» of knowledge and international attitudes, the owning-family should positively influence the internationalization process by allowing the organization to be more flexible. A strong international culture can help to overcome the psychic distance and allow for a broader market and internationalization knowledge [Corbetta and Montemerlo 1995].

The rationale behind this positive effect is that international orientation could moderate the perceived risk pertaining to international expansion. For example, in their empirical study, Acedo and Jones [2007] found that international orientation lead to higher levels of proactivity and a lower perception of risk. Their results show that internationally-oriented individuals are generally better informed and therefore 
more likely to behave proactively and be less concerned, or at least better informed about risk in relation to international opportunities. Consequently, the openness of the owner-manager and the richness of his international orientation would resolve the dilemma of «protection vs development» in favor of development which despite its risk would permit the growth of the family's wealth and its perpetuation.

Figure 1. The moderating Role of manager's international orientation

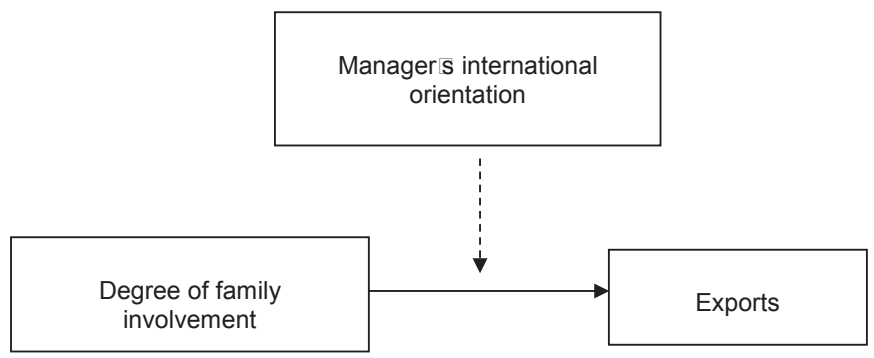

Source: own work.

Therefore, it is possible to believe that international orientation can enhance the positive influence of involvement in ownership on export intensity while minimizing the negative effect played by involvement in management. In sum, the following three hypotheses are proposed:

H1b: The manager's international orientation moderates the relationship between the family involvement in ownership and exports; when it is high, the family involvement in ownership would have a positive impact on exports.

H2b: The manager's international orientation moderates the relationship between the family involvement in management and exports; when it is high, the family involvement in management would have a positive impact on exports.

H3b: The manager's international orientation moderates the relationship between the family involvement (both in ownership and management) and exports; when it is high, the family involvement would have a positive impact on exports.

\section{Methodology and results}

\section{Methodology and sample}

The study is based on a set of 125 French family SMEs ${ }^{13}$ issued from a sample of 168 responses to a questionnaire survey conducted online in 2003. The surveyed

${ }^{13}$ This study is concerned about SMEs which are defined as firms having a turnover less than 50 million $€$ and workforce of less than 250 employees. 
"population" was compiled from various sources (Diane Database, Kompass Database, French chambers of commerce exporting firms' files). This "population" comprising 10,354 individuals consists of internationalized, exporting or multinational family firms. Three criteria for identification of family firms have been adopted: holding a blocking share of at least $33 \%$ of equity; involvement of at least one owning-family member as an executive or a manager; self-identification of the firm as a family firm. Two emailing waves were made and the respondents i.e. managers were invited to connect to the online questionnaire and respond to the survey. 168 complete responses were received of which 128 firms were finally classified as family firms ${ }^{14}$.

88 companies $(70.4 \%$ of the sample) are in manufacturing, 29 others operate in the trade sector and 8 are service firms ${ }^{15}$. The quite heterogeneous sample is composed of both young family businesses and older ones founded in the $18^{\text {th }}$ century. The average age is 50 years and thirteen companies (10.5\% of the sample) were founded before 1900. Internationalization year is on average about 20 years after the foundation year. For half of the firms in the sample, this period preceding the trigger of internationalization is less than 9 years. International experience, expressed by the number of years of operation abroad, is on average about 30 years and the average export turnover is $32.09 \%$.

\section{Dependent variable}

The dependent variable of the different models - which will be described below - are the firm's export intensity expressed in terms of sales abroad. Our study relies indeed on only one indicator of the degree of internationalization because the sample consists exclusively of SMEs opting infrequently for takeovers or development of subsidiaries abroad [Brouthers et al. 2009; Reuber and Fisher 1997] ${ }^{16}$. Indeed, the most frequently used operation mode is direct export (used by $88 \%$ of firms) and only 17 firms (approximately 13.6\% of the sample) have opted for the establishment of subsidiaries during their internationalization process.

${ }^{14}$ The chosen means of contact (web survey) produces a quite high non-response rate compared to a conventional mail surveys. Taking into account 2441 undelivered e-mails (due to incorrect or not updated addresses at the time of the survey), a response rate of $2.12 \%$ is computed (168 / (103542441)).

${ }^{15}$ In fact, theses three aggregated sectors were created based on the following actual activities (French NAF 2003): Manufacturing (Mining: 0.8\% of total firms; Manufacturing: 68\%; Construction: 1.6\%); Trade (Commerce: 21.6\%; Transport and communications 1.6\%); Service (Real estate and business services $6.4 \%$ ).

${ }^{16}$ This is indeed only one among the numerous dimensions of the internationalization degree. Many authors (such as Sullivan 1994) pointed out the disadvantages of a unidimensional measure of the concept of internationalization and recommend a multidimensional measure reflecting the performance, structural and attitudinal dimensions. 


\section{Independent variables}

- Degree of involvement in ownership (DIK): The degree of involvement in ownership is measured by the percentage of equity held by the owning-family. This ratio is measured by a quantitative variable obtained from the Diane database. The owning-family is either explicitly identified in Diane as the firm's reference shareholder or identified by comparing the majority shareholder's name with the surname of the executive(s). This variable has a mean of $68.7 \%$.

- Degree of involvement in management (DIG): This variable is typically measured by the share of executives from owning-family and/or the share of operational managers and/or directors participating in governance bodies. In our study, the degree of family involvement in the management is measured by the relative weight of family members involved in board of directors. This choice was rendered necessary for two reasons. First, conceptually, we had to avoid redundancy between this independent variable and the moderating variable which measures a manager's attitude - all the more that the quasi-totality of our sample's SMEs are directed by a family manager. Then the integration in our regressions of such a variable whose variance is low may have produced insignificant results. 102 companies (80.8\% of the sample) declared adopting board of directors or an equivalent monitoring body. We observe that the average influence of owning-family members within these boards is $77.43 \%{ }^{17}$.

To reduce multicollinearity between the interacting variables (independent and moderator) and the various multiplicative terms to be implemented in our models, it is recommended to center all variables [El Akremi and Roussel 2003].

\section{Moderating variable}

Dichtl et al. [1990] elaborated a measure of international orientation which comprehends objective and subjective characteristics. Objective characteristics are: age, level of education, command of foreign languages, vacations spent abroad, longer stays abroad and number of previous jobs. More recent studies [such as Acedo and Jones 2007; Belso-Martinez 2006] focus on educational level, languages spoken, experience abroad and likeness to travel. Sometimes, the foreign origin of the entrepreneur is an indicator of his international orientation [Cavusgil 1984; Lim et al. 1991; Bloodgood et al. 1996].We chose to measure manager's international orientation responses to the following items:

- Languages: Number of languages practiced by the manager.

- Travels: Average annual number of trips abroad made by the manager.

- Origin (binary): Does the manager's family have a foreign origin? In total, the score for this variable is obtained by aggregating the values for these

${ }_{17}$ Therefore, the various models incorporating the variable DIG will be limited to 102 firms. A listwise procedure is indeed adopted. 
indicators via a principal component analysis ${ }^{18}$ - the first two (languages, travel) being standardized. The scale showed acceptable reliability as Cronbach's alpha was $0.563^{19}$. For specialists, when a scale is in the development stage, a Cronbach's alpha equal to 0.5 indicates a low internal consistency but can be acceptable [Nunnally 1978, George and Mallery 2003]. The number of foreign languages spoken by owner-managers varies between 0 and 6 and has an average of 1.85. The annual number of trips is between 0 and 75 with an average of 6.72 trips per year. The observation of the characteristics of the synthetic variable shows a minimum of -1.29 and a maximum of 4.93 , the median being -0.194 .

\section{Control variables}

Thanks to the resource-based of the firm [Barney 1991], it is possible to conceive internationalization as a strategic process mobilizing resources in general and distinctive resources more especially [Lorino 1996]. For Welch and Luostarinen [1988], resource endowment explains the low international orientation of small businesses and the more intense of largest ones. The latter are more likely to initiate earlier their internationalization process which may evolve faster. For their part, Andersen and Kheam [1998] observe that firms controlling a weak resource base don't manifest any intention to expand overseas. Among the resources and skills critical to internationalization and exports, organizational learning has been highlighted by many studies. For example, Tallmann and Fladmoe-Lindquist [1994] advocate that the interest in internationalization and learning capability are as important as tangible resources in the context of international business development. Indeed, firms with limited resources and capacity for organizational learning do not pursue a meaningful international or multinational development because they do not possess the necessary internationalization knowledge.

Consequently, our study mobilizes the following four control variables:

- Firms' size which can provide information on firm's maturity and development of its resources and explain, therefore, a proportion of the variability of the dependent variables. Indeed, for Dhanaraj and Beamish [2003], firm size is a reliable surrogate for the various resources a firm may be endowed with and can be a proxy for quality of management, technological intensity or investment in research and development [Ali 2004]. Specifically to family firms, Claver et al. [2007] observe that larger family firms can reach stages in the

${ }^{18}$ The PCA shows uni-dimensionality of the construct and produces a single factor explaining $53.38 \%$ of the variance.

19 Since this variable is operationalized by items measured on different scale types, it is recommended to calculate the standardized version of Cronbach's alpha. Indeed, according to Sun et al. (2007), when items are not strictly parallel, the Cronbach's alpha coefficient provides a lower bound estimate of true reliability. This estimate may be further biased downward when items are dichotomous. 
internationalization process which require a higher degree of commitment. We chose to measure size through total sales.

- Then, we controlled for firm's age as Yip, Biscarri, and Monti [2000] found that older firms have relatively more international market commitment and organizational resources and then should manifest a higher level of international involvement. For these two control variables, we used a logarithmic transformation that would reduce the potential distortion in the results caused by outliers.

- In addition, organizational learning was measured through a four item Likert scale trying to measure learning practices used by firms during their internationalization ${ }^{20}$. The unidimensional scale (a PCA produced a single factor explaining $47.71 \%$ of the variance) shows acceptable reliability according to the Cronbach's alpha criteria (0.63).

- Finally, because internationalization may vary by industry, we included two dummy variables reflecting the firms' main industry group (trade and services), "manufacturing" being the reference sector.

Table 1 provides variable correlations and multicollinearity diagnosis.

${ }^{20}$ Item 1: Our know-how relating to internationalization was acquired through the biring of internationally experienced managers; Item 2: Ourknow-how relating to internationalization was acquired through a training program for managers to be responsible for internationalization; Item 3: Our know-how relating to internationalization was acquired through a collective effort of reflection and transposition of knowledge and past experiences; Item 4: Imitating decisions of more experienced firms has allowed us to gain experience and knowledge about international operations. 
Family Involvement in the Firm and Exports in the Family SME...

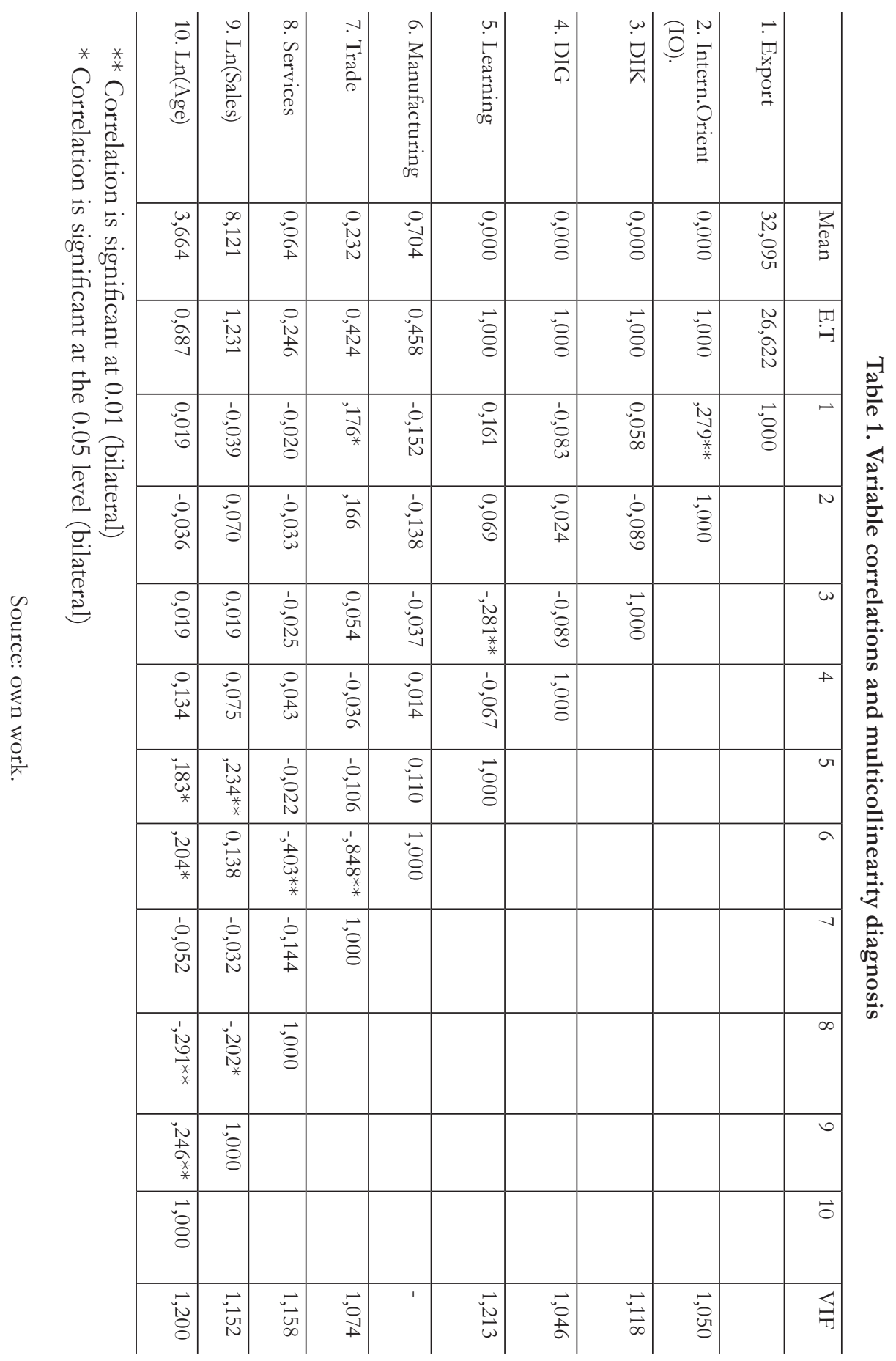




\section{Results and interpretations}

To test our hypotheses, TOBIT multiple regressions were performed ${ }^{21}$. The two-step procedure of "moderated multiple regression" was adopted [El Akremi and Roussel 2003]. First, a regression including control variables, the independent and the moderator variables was performed. Then, in a second step, the product of independent and moderating variables representing the non-linear interaction effect was integrated. The moderator role is established if the regression coefficient associated with the interaction effect is statistically significant and the coefficient of determination $\left(\mathrm{R}^{2}\right)$ associated with the second regression is better than the first. The procedure was carried out three times in order to detect the possible moderating effect of manager's international orientation on DIK, DIG then the two variables simultaneously. Before performing the regressions, the independent variables were examined for collinearity. Results of the variance inflation factor (all less than 2.0) suggest that the estimated $\beta$ s are well established in the regression models. Table 2 exhibits the results of the TOBIT regressions.

\footnotetext{
${ }^{21}$ This choice is justified by the nature of the independent variable whose values are in the range $[0,1]$
} 


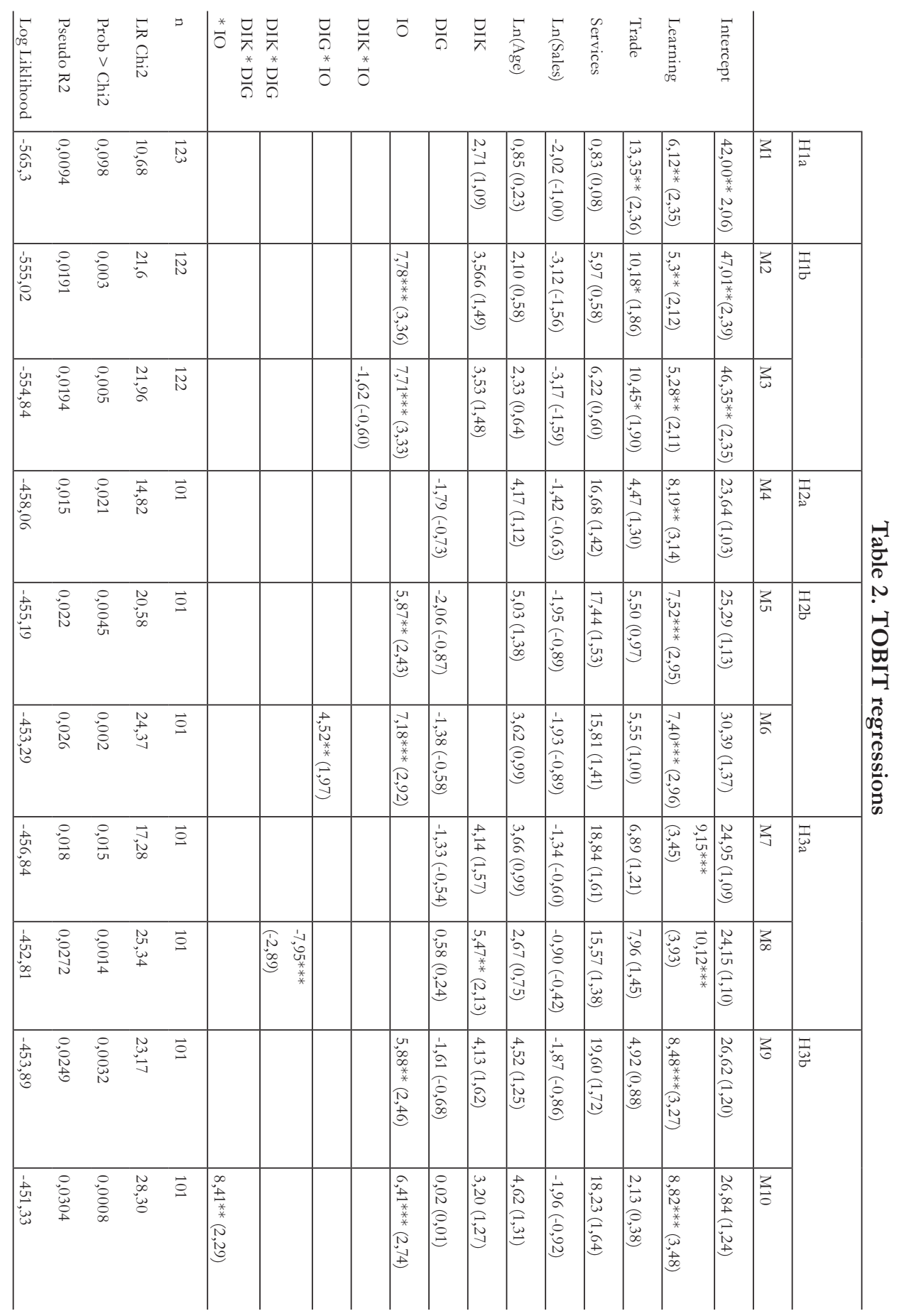


* The coefficient is significant at the 0.10 level

$* *$ The coefficient is significant at the 0.05 level

*** The coefficient is significant at the 0.01 level

T-statistics are in parentheses

Source: own work.

Our regressions result in no significant main effect of involvement in ownership on export intensity (see M1). If the positive effect of international orientation on exports is supported (see M2), its moderating role is not established because the regression coefficient is not significant (see M3). Therefore, H1b is not supported and thus international orientation should be considered as an ordinary independent variable and not as a moderator.

Moreover, if the regression coefficient linking managerial involvement and exports is of the expected sign, it is not significant (see M4), which prevents us from supporting the hypothesis H2a. In contrast, a significant effect of the moderator variable is observed (in model M6: regression coefficient is 4.52 and is significant at the threshold of $1 \%$ ). Note that obtaining a significant interaction term in the absence of a main effect is acceptable because the direct effect is not conceptually necessary to test a moderating effect [Eg. Covin and Slevin 1989; Tsao et al. 2009]. Therefore, it is possible to say that a strong manager's international orientation makes the effect of involvement in management favorable to exports. Thus, H2b is verified.

Our results confirm the hypothesis 3 a since a negative and significant effect of interaction between DIK and DIG is obtained in model M8 (regression coefficient is -7.95 and is significant at the threshold of $0.1 \%$ ). The model reveals that the observed interaction effect is associated with a positive effect of involvement in ownership on export intensity. In accordance with hypothesis $\mathrm{H} 1 \mathrm{a}$, it is therefore possible to say that ownership involvement positively influences exports but holding together the roles of shareholder and manager seems to be unfavorable to the development of export activities. In sum, taking into account the results of models M1 and M8, we could say that hypothesis H1a is partially supported.

Finally, as expected, models 9 and 10 show that the interaction effect between international orientation and the two facets of family involvement is positive and significant. Therefore, even if holding the two roles of ownership and management seems detrimental to the development of exports ( $\mathrm{H} 3 \mathrm{a})$, the influence of manager's international orientation seems to reverse the direction of this effect thus positively impacting the export intensity.

Regarding control variables, we first note the positive and significant effect of learning on export sales. Moreover, thanks to the first three models, we observe that the fact of belonging to the trade sector seems, all things being equal, exerting 
a stronger influence on our dependent variable than does the manufacturing sector. Finally, no significant effects of age and sales impact export sales.

\section{Discussion and conclusions}

\section{Contributions}

Our study extends previous research on family firms' internationalization in that it helps explain how family ownership and management influence exports. Indeed, prior literature does not agree on the impact of family firms on internationalization [Sciascia et al. 2012]. While some scholars have found a positive relationship between family firms and internationalization [Zahra 2003], other studies have shown that the propensity of family firms to internationalize is low [Fernandez and Nieto 2005, 2006; Okoroafo 1999]. We contribute to the literature by analyzing how manager's international orientation may help to integrate these inconsistent empirical results and drive research on this topic. Thus, we incorporate insights from agency theory, stewardship and the socioemotional wealth approach (SEW) into the theoretical framework on the relationship between family firms and exports. A strong manager's international orientation seems to be an asset to our sample's family firms since it results in a higher international commitment expressed in terms for export sales. In all models tested, this variable plays a significant role either as an independent variable or as a moderating variable. These results are consistent with those of Manolova et al. [2002] explaining that owners/founders or managers who have more positive perceptions of the international environment will also be more likely to internationalize their own small businesses.

In accordance with the descriptions of stewardship theory describing the manager as a strategic asset for the family firm, the role of the latter is important for the strategic development of his firm. Therefore, if he has the qualities and skills required, he could be able to lead the firm into new development pathways. In particular, his international orientation is a key skill that induces a positive influence of family involvement in management on export. This variable may constitute a factor permitting to achieve support and commitment to exports from family members involved in management. Dispelling doubts about internationalization thanks to his better knowledge of foreign markets and business practices, the manager may obtain the support of the owning-family and help defeat the forces of stagnation and inertia. Therefore, it is possible for family firms to achieve a successful global position as Carr and Bateman [2009] observed that the top world family firms are not less "worldwide-oriented" in terms of international configurations adopted.

Our research found no simple effect of family involvement in ownership on export sales ${ }^{22}$. Some authors reached a similar result and explained it by the existence

\footnotetext{
${ }^{22}$ But as a reminder, a positive effect associated with the interaction with DIG is observed in
} 
of a possible nonlinear relationship (eg. quadratic) between family ownership, family involvement in management and internationalization. For example, Sciascia et al. [2010] show that international entrepreneurship activities of family firms are positively influenced by family ownership until an average level of control (estimated at 53\%) and that beyond that threshold this influence becomes negative. Similarly, Carr and Bateman observe that international involvement decreases slightly when family ownership is between $30 \%$ and $50 \%$ and then increases markedly as compared to non-family firms. Further tests carried out in this sense don't lead to any significant results on the basis of our sample's data. As Sciascia et al. [2010] stated, family ownership may have both positive and negative effects on internationalization. Depending on the level of family ownership, stewardship or stagnation will prevail thus influencing positively or negatively international involvement.

For its part, our research shows that involvement in ownership can play a positive role in increasing exports but in the presence of a strong involvement in management, this positive effect could be annihilated implying a negative influence on exports. When the family assumes its role as an owner and delegates decisionmaking power, there is a good chance that the goals pursued by the manager will be consistent with value maximizing: in this sense, exportation can be a vehicle for achieving this goal. In contrast, when the family monopolizes all powers by adding to its shareholder role an effective involvement in firm's management, especially through monitoring bodies, there might be a risk of pregnancy of non-economic and/or non-rational goals that could negatively affect the choice of growth strategies like exportation (for example: heritage preservation, succession, etc.). As explained before, appointment of family members in governance bodies may simply reflect an act of SEW preservation as the owning-family feels the obligation to serve its members aspirations or career needs. Besides, as boards may constitute a simple formality because they're heavily dominated by owning families, it is not surprising that their play a non-significant or sometimes detrimental role as for firm's strategic development. Moreover, a strong managerial involvement can be unfavorable to the firm if intra-family conflicts affect the firm and therefore block strategic initiatives. Again, our results show (in M10) that the negative influence of family involvement is reversed by the role of manager's international orientation who can temper risk aversion, "bad" effects of altruism and the effect of potential conflicts.

Note that the poor result about the "simple" effect (in M4) of involvement in management on exports may be due to the measure used i.e. the proportion of family members in boards. It is possible that this structure constitutes for our sample's family firms merely an entrenchment mechanism of the manager and/ or the family and don't play an active role. Indeed, despite its valuable potential

model M8. 
contribution, for many family firms, the board is simply set up in order to comply with legal obligations and is totally indentured to the owning-family. Thus, it acts as a rubber stamp and endorses the decisions taken in actual and informal power arenas such as the family's inner circle.

\section{Implications}

Our study has several implications for family firm's owners. The very first implication is the invitation to develop an international attitude for the family to which the manager may belong in order to increase international commitment. Indeed, for Acedo and Jones [2007], attention paid to the cognition of individuals towards internationalization may positively affect the speed with which it commences and ultimately reach successful performance. For Nguyn et al. [2006], international orientation is positively influenced by information internalization: firms should adopt market-oriented and learning-oriented approaches in order to place high values on information acquisition and internalization. These approaches would encourage individuals to actively gather information and knowledge from a variety of sources, such as foreign market visits, trade fairs and the internet, enabling the information internalization process [Nguyn et al. 2006]. For Swinth and Vinton [1993], the international orientation of the family grows easily if family members are exposed to the international environment from their early age: for instance, practiced foreign languages and journeys abroad contribute significantly to the development of international orientation. More generally, the "family's international culture" develops through various means as family members' travels, their work experience abroad, their curiosity and openness to foreign cultures. Moreover, belonging to international associations or networks, establishing relationships with family businesses in other countries, younger generations' apprenticeship abroad are practices whose implementation allows the firm and family to widen their international orientation [Swinth and Vinton 1993; Gallo and Pont 1996; Corbetta and Montemerlo 1995; Gallo et al. 2002]. Consequently, if the owning-family implements and develops an orientation and particularly a culture that supports internationalization and prepares the family members for it, this process will be triggered more easily and the internationalization degree achieved will be even stronger.

If not internally developed, firms might instantly acquire international orientation by hiring managers having strong international experience, high levels of education and language abilities [Acedo and Jones 2007]. But above all, Claver et al. [2009] found that long term vision is a factor that favors international behavior which permits progress toward more advanced stages in the internationalization process. Particularly, it increases the likelihood of using entry modes involving a high level of resource commitment. 
Manager's international orientation, as a capability of the firm, must be nurtured and perpetuated through generations. Generally, research claims that business transfer between generations could weaken the entrepreneurial spirit and that new generations could be tempted to exploit the achievements of the firm and rest on their laurels especially when their motivation to take over the family business is weak [Ward 1987]. The classical post-succession conflicts would be challenging as they may push successors to focus on their resolution and neglect strategic issues such as openness to international context which would lead to a weaker international orientation. Therefore, it is necessary that the manager could transfer this capability to potential family successors as well as his other tacit knowledge during the process of generational transfer.

\section{Limitations and Future Research}

The study of family firm internationalization and exports in particular has often focused on factors inhibiting this strategic choice - in particular in an attempt to provide counsel to such organizations while they internationalize. Rarely did the research highlight the factors promoting internationalization [Gallo and Pont 1996]. However, despite the supposed rigidity of the family firm, this entity has abundant resources and capabilities playing an important role in its strategic development [Habbershon and Williams 1999]. In particular, the present study shows that manager's international orientation is a driving force for exports in family SMEs.

Our research has certain limitations. First, a major weakness is the absence of a synchronic approach as the dependent and independent variables are measured at the same moment. In that, we assume that the international orientation is a "stable" attitude of the manager and that this orientation is prevailing particularly before internationalization trigger. Measuring this construct before internationalization is simply quasi-impossible for many of the sample's firms. This simplifying approach could be enhanced, in a future research, by implementing a more longitudinal approach which would be valuable to analyze the causal relationships between this variable and internationalization. A second limitation is that the characteristics of the sample may limit the generalizability of the results. Besides, the institutional context surrounding French SMEs may have an influence on results and it may be useful to implement a larger study allowing for country comparisons. Moreover, does the size of firms allow moderating observed relationships? For example, would the positive effect of ownership on exports be different if the sample consisted of SMEs and larger firms? We believe that these are relevant avenues for future research.

Another improvement of our research pertains to the limited reliability of the international orientation construct. The measure of international orientation could be enhanced, for instance, by the use of a psychometric approach such as that used 
by Knight and Kim [2009] or Nguyen et al. [2006]. We assumed that manager's answers to the items could be a reliable representation of his views. While this choice is critisizable because of the partiality and subjectivity of respondents it may be avoided in a future research if multi-responses from multiple organization's members are obtained in order to inform about their individual international orientations and the entire firm's international orientation. Furthermore, future research could extend the international orientation construct and try to measure it for the entire owning-family.

Moreover, the models could be improved by incorporating other assumptions and reciprocal relations between variables. Indeed, a structural model could be tested by introducing links between dependent, independent and control variables. Conceptually, this research could be improved by introducing in a unique model variables simultaneously promoting and inhibiting family firm's internationalization. It would be interesting to observe their combined or simultaneous effects on the degree of internationalization of the family firm.

\section{References}

Abdellatif M., Amann B., Jaussaud, J. (2010), Family versus nonfamily business: A comparison of international strategies, "Journal of Family Business Strategy", 1(2), 108-116.

ACEDO F., FLORIN J. (2006), An entrepreneurial cognition perspective on the internationalization of SMEs, "Journal of International Entrepreneurship", 4(1), 49-67.

Acedo F., Jones M. (2007), Speed of internationalization and entrepreneurial cognition: Insights and a comparison between international new ventures, exporters and domestic firms, 'Journal of World Business", 42(3), 236-252.

ALI M.Y. (2004), Impact of firm and management related factors on firm export performance, "Journal of Asia Pacific Marketing", 3(2), 5-20.

Andersen O., Kheam L. (1998), Resource-based Theory and International Growth Strategies: An exploratory Study, 'International Business Review', 7(2), 163-184.

Arrègle J-L., Mari I. (2010), Avantages on désavantages des entreprises familiales ? Principaux résultats de recherches et perspectives, 'Revue française de gestion', (1), 87-109.

Astrachan J., Klein S., Smyrnios K. (2002), The F-PEC Scale of Family Influence: A Proposal for Solving the Family Business Definition Problem, 'Family Business Review', 15(1), 45-58.

Autio E., Sapienza H., Almeida J. (2000), Effects of Age at Entry, Knowledge Intensity and Imitability on International Growth, "Academy of Management Journal”, 43(5), 909-924.

Barney J. (1991), Firm Resources and Sustained Competitive Advantage, "Journal of Management", 17(1), 99-121.

Belso-Martinez J. (2006), Why are some Spanish manufacturing firms internationalizing rapidly? The role of business and institutional international networks, "Entrepreneurship and Regional Development", 18, 207-226. 
Bloodgood J., Sapienza H., Almeida J.G. (1996), The Internationalization of New High-Potential U.S. Ventures: Antecedents and Outcomes, "Entrepreneurship: Theory and Practice", 20, 61-76.

Boyd B., Goto T., Hollensen S. (2010), Internationalisation of family businesses - evidences from joint venture formations at Danfoss, "International Journal of Management Practice", 4(3), 253-272.

Brouthers L., Nakos G., Hadjimarcou J., Brouthers KD. (2009), Key factors for successful export performance for small firms, "Journal of International Marketing”, 17, 21-38.

Calabrò A., Mussolino D. (2013), How do boards of directors contribute to family SME export intensity? The role of formal and informal governance mechanisms, "Journal of Management and Governance", 17(2), 363-403.

Carr C., Bateman S. (2009), International Strategy Configurations of the World's Top Family Firms. Another Factor Affecting Performance, "Manag Int Rev", 49, 733-758.

Casillas J., Acedo F. (2005), Internationalisation of Spanish family SMEs: an analysis of family involvement, "International Journal of Globalisation and Small Business", 1(2), 134-151.

Cavusgil ST. (1980), On the Internationalization Process of Firm, "European Research", 8, 273-281.

Cavusgil ST. (1984), Organizational Characteristics Associated with Export Activity, "Journal of Management Studies", 1, 3-22.

Cavusgil ST., NaOr J. (1987), Firm and Management Characteristics as Discriminants of Export Marketing Activity, “Journal of Business Research”, 15, 221-235.

Cerrato D., Piva M. (2012), The internationalization of small and medium-sized enterprises: the effect of family management, human capital and foreign ownership, "Journal of Management and Governance", 16(4), 617-644.

CHen H. (2011), Internationalization in Taiwanese family firms, "Global Journal of Business Research", 5(4), 15-24.

Chrisman J., Chua J., LITZ R. (2004), Comparing the Agency Costs of Family and Non-Family Firms: Conceptual Issues and Exploratory Evidence, "Entrepreneurship Theory and Practice", 28(4), 335-355.

Claver E., Rienda L., Quer D. (2007), The internationalisation process in family firms: Choice of market entry strategies, "Journal of General Management”, 33(1), 1-14.

Claver E., Rienda L., Quer D. (2009), Family Firms' International Commitment: The Influence of Family-Related Factors, "Family Business Review”, 22(2), 125-135.

Cohen T., Lindberg R. (1974), Survival and Growth: Management Strategies for the Small firm, New York, AMACOM.

Collinson S., Houlden J. (2005), Decision-Making and Market Orientation in the Internationalization Process of Small and Medium-Sized Enterprises, "Management International Review", 45(4), 413, 436.

Corbetta G., Montemerlo D. (1995), Internationalization Strategies in Family Businesses: Implications for Family and Firm, Research paper, SDA Bocconi, Business Policy Department.

Covin J.G., SLEvin D.P. (1989), Strategic management of small firms in hostile and benign environments, "Strategic Management Journal", 10(1), 75-87. 
Crick D., Bradshaw R., Chaudry S. (2006), Successful internationalising UK family and nonfamily-owned firms: A comparative study, "Journal of Small Business and Enterprise Development", 13(4), 498-512.

Davis J., Schoorman F., Donaldson L. (1997), Toward a Stewardship Theory of Management, "Academy of Management Review", 22, 20-47.

Dhanaraj C., Beamish P.W. (2003), A resource-based approach to the study of export performance, "Journal of Small Business Management", 41(3), 242-261.

Dichtl E., Koeglmayr H-G., Mueller S. (1990), International Orientation as a Precondition for Export Success, "Journal of International Business Studies”, 21(1), pp. 23-40.

Donckels R., FröHlich E. (1991), Are Family Businesses Really Different? European Experiences from STRATOS, "Family Business Review” 4(2), 149-160.

El Akremi A., Roussel P. (2003), Analyse des variables modératrices et médiatrices par les méthodes d'équations structurelles: Applications en GRH. Paper presented at the AGRH Conference, May, Grenoble (France).

Eriksson K., Lindstrand A., Majkgard A., Deo Sharma D. (2000), Path Dependence and Knowledge Development in the Internationalization Process, "Management International Review", 40, 307-328.

Evrard Y., Pras B., Roux E. (2000), Market: Etudes et recherches en marketing, Paris, Dunod.

FAma E., Jensen M. (1983), Separation of Ownership and Control, "Journal of Law and Economics", 26, 301-325.

FERnANDez Z., NieTo J. (2006), Impact of Ownership on the International Involvement of SMEs, "Journal of International Business Studies", 37(3), 340-351.

Gallo M.A., Sveen J. (1991), Internationalizing the Family Business: Facilitating and Restraining Factors, "Family Business Review", 4, 181-190.

Gallo M., Estapé M. (1992), The Internationalization of the Family Business: Exploration of the Differences Compared with Non-Family Businesses, Research paper, IESE - n²30 Bis, june 1992).

Gallo M., Luostarinen R. (1992), Internationalization: A Challenging Change for Family Businesses. Paper presented at the Family Business Network Conference, Barcelona.

Gallo M., Pont C. (1996), Important Factors in Family Business Internationalization, "Family Business Review", 9(1), 45-59.

George D., Mallery P. (2003), SPSS for Windows step by step: A simple guide and reference. 11.0 update, Boston, Allyn \& Bacon.

Gersick K-E., Davis J-A., McCollom H., Lansberg I. (1997), Generation to Generation: Life Cycles of the Family Business, Boston, Harvard Business School Press.

Grapentine T. (1995), Dimensions of an Attribute, "Marketing research", 7(3), 19-28.

Graves C., Thomas J. (2008), Determinants of the internationalization pathways of family firms: An examination of family influence, "Family Business Review", 21(2), 151-167.

Graves C., Thomas J. (2006), Internationalization of Australian family businesses: A managerial capabilities perspective, "Family Business Review", 19(3), 207-224. 
Gudmundson D., Hartman E., Tower C. (1999), Strategic Orientation: Differences between Family and Nonfamily Firms, "Family Business Review", 12(1), 27-39.

Habbershon T., Williams M. (1999), A Resource-Based Framework for Assessing the Strategic Advantages of Family Firms, Family Business Review, 12(1), 1-25.

Hambrick D., Geletkanycz M., Fredrickson J. (1993), Top Executive Commitment to the Status Quo: Some Tests of its Determinants, "Strategic Management Journal”, 14, 401-418.

Harvey J. (1999), Owner as Manager, Extended Horizons and the Family Firm, "International Journal of Economics and Business", 6(1), 41-55.

Jensen M. (1994), Self-interest, Altruism, Incentives and Agency Theory, "Journal of Applied Corporate Finance", 7(2), 40-45.

Johanson J., Vahlne J-E. (1977), The Internationalization Process of the Firm - A Model of Knowledge Development and Increasing Foreign Market Commitments, "Journal of International Business Studies", 18(1), 23-32.

Katz J., Niehoff B. (1998), How Owners Influence Strategy - A Comparison of Owner-Controlled and Manager-controlled Firms, "Long range Planning”, 31(5), 755-761.

Kelly L., Athanassiou N., CRITTENDEN W. (2000), Founder Centrality and Strategic Behaviour in the Family-owned Firm, "Entrepreneurship Theory and Practice", 25(2), 27-42.

Kesner I., Sebora T. (1994), Executive Succession: Past, Present \& Future, "Journal of Management”, 20(2), 327-372.

Kontinen T., OJALA A. (2010), Internationalization pathways of family SMEs: psychic distance as a focal point, "Journal of Small Business and Enterprise Development", 17(3), 437-454.

Kontinen T., Ojala A. (2010), The internationalization of family businesses: A review of extant research, "Journal of Family Business Strategy", 1(2) 97-107.

Kontinen T., Ojala A. (2011), Network ties in the international opportunity recognition of family SMEs, "International Business Review”, (20(4), 440-453.

Kontinen T., Ojala A. (2011), International Opportunity Recognition among Small and MediumSized Family Firms, “Journal of Small Business Management”, 49(3), 490-514.

KNight G., Kim D. (2009), International business competence and the contemporary firm, "Journal of International Business Studies", 40, 255-273.

Kim Y.Y., GAO F.Y. (2013), Does family involvement increase business performance? Family-longevity goals' moderating role in Chinese family firms, "Journal of Business Research", 66(2), 265-274.

Larimo J. (2013), Small and Medium-Size Enterprise Export Performance, "International Studies of Management \& Organization”, 43(2), 79-100.

Levy O., Beechler S., Taylor S., Boyacigiller N.A. (2007), What we talk about when we talk about 'global mindset': Managerial cognition in multinational corporations, "Journal of International Business Studies”, 38(2), 231-258.

Lim J., Sharkey T, Kim K. (1991), An Empirical Test of an Export Adoption Model, "Management International Review", 31, 51-62.

Lloyd-Reason L., Mughan T. (2000), SME Internationalisation and the Key Role of the Owner-Manager, "Journal of Small Business and Enterprise Development", 9(2). 
Luostarinen R. (1979), Internationalization of the Firm. Unpublished Doctoral Dissertation. Acta Academiae Oeconomicae Helsingiensis A:30. The Helsinki School of Business Administration, Finlande.

LUOSTARINEN R. (1994), Internationalization of Family Enterprises. Research paper, CIBR Working Papers, Series Z-1.

Luostarinen R., Hellmann H. (1995), The Internationalization Processes and Strategies of Finnish Family Firms. Research paper, CIBR Research Papers, Series Y-1.

Manolova T., Brush C., Edelman L., Greene P. (2002), Internationalization of Small Firms: Personal Factors Revisited, "International Small Business Journal”, February (20), 9-31.

McDougall P., Shane S., Oviatt B. (1994), Explaining the Formation of International New Ventures: The Limits of Theories From International Business Research, "Journal of Business Venturing", 9, 469-487.

Melin L., Nordquist M. (2000), Corporate Governance in Family Firms: The Role of Influential Actors and the strategic Arena, Paper presented at the ICSB Conference, Brisbane, (June).

Miller D., Steier L., Le Breton-Miller I. (2003), Lost in Time: Intergenerational Succession, Change, and Failure in Family Business, "Journal of Business Venturing", 18, 513-531.

Miocevic D., Crnjak-Karanovic B. (2011), Cognitive and Information-Based Capabilities in the Internationalization of Small and Medium-Sized Enterprises: The Case of Croatian Exporters, "Journal of Small Business Management”, 49(4), 537-557.

Moen Ø., Servais P. (2002), Born global or gradual global? Examining the export behavior of small and medium-sized enterprises, "Journal of International Marketing”, 10(3), 49-72.

Moloktos L. (1991), Change and Transition and Family Businesses. Paper presented the Family Business Network Conference, Barcelona.

Muñoz F., SÁNCHEz M.J. (2012), Do family ties shape the performance consequences of diversification? Evidence from the European Union, "Journal of World Business", 47(3), 469-477.

Mustakallio M., Autio, E. (2001), Optimal Governance in Family Firms. Paper presented at the Babson College Entrepreneurship Conference, Jönköping.

Naldi L., Nordqvist M. (2008), Family Firms Venturing into International Markets: A Resource Dependence Perspective. Paper presented at the Babson College Entrepreneurship Conference. The University of North Carolina at Chapel Hill.

Nguyen T., Barrett N., Fletcher R. (2006), Information internalisation and internationalization - Evidence from Vietnamese firms, "International Business Review", 15(6), 682-701.

Nummela N., Saarenketo S., Puumalainen K. (2004), A global mindset-a prerequisite for successful internationalization?, 'Canadian Journal of Administrative Sciences/Revue Canadienne des Sciences de l’Administration', 21(1), 51-64.

Nunnally J. (1978), Psychometric Theory, New York, McGraw-Hill.

Okоroafo S., Кон A. (2010), Family Businesses' Views on Internationalization: Do They Differ by Generation?, "International Business Research", 3(1), 22-28. 
Perlmutter H. (1969), The Tortuous Evolution of the Multinational Corporation, "Columbia Journal of World Business", 4(1), 9-18.

PETT T., Francis J., WolfF J. (2004), Examining SME internationalization motives as an extension of competitive strategy, "Journal of Business and Entrepreneurship", 16(1), 46-65.

REID R.S. (1981), The Decision-maker and Export Entry and Expansion, "Journal of International Business Studies", 12(2), 101-112.

Reuber A.R., Fischer E. (1997), The influence of the management team's international experience on the internationalization behaviors of SMEs, "Journal of International Business Studies", 28(4), 807-825.

Ruzzier M., Antonci B., Hisrich R., Konecnik M. (2007), Human Capital and SME Internationalization: A Structural Equation Modeling Study, "Canadian Journal of Administrative Sciences", 24(1), 15-29.

Salvato C. (2002), Towards a Stewardship Theory of the Family Firm. Paper presented at the $13^{\text {th }}$ FBN Conference. Helsinki, 2002.

SAnchez-Bueno M.J., Usero B. (2014), How may the nature of family firms explain the decisions concerning international diversification?, "Journal of Business Research", 67(7), 1311-1320. DOI:10.1016/J.JBUSRES.2013).09.003.

Schulze W., Lubatkin M., Dino R., Buchholtz A. (2001), Agency Relationships in Family Firms: Theory and Evidence, "Organization Science", 12(2), 99-116.

Schulze W., Lubatkin M., Dino R. (2003), Exploring the Agency Consequences of Ownership Dispersion Among the Directors of Private Family Firms, "Academy of Management Journal", 46(2), 179-194.

Schulze W., Lubatkin M., Dino R. (2003), Exploring the Agency Consequences of Ownership Dispersion Among the Directors of Private Family Firms, "Academy of Management Journal", 46(2), 179-194.

Sciascia S., Mazzola P. (2008), Family Involvement in Ownership and Management: Exploring Nonlinear Effects on Performance, "Family Business Review", 21(4), 331-345.

Sciascia S., Mazzola P., Astrachan J., Pieper T. (2010), The role of family ownership in international entrepreneurship: exploring nonlinear effects, "Small Business Economics", 38(1), 15-31.

Segaro E.L., Larimo J., Jones M.V. (2014), Internationalisation of family small and medium sized enterprises: The role of stewardship orientation, family commitment culture and top management team, "International Business Review", 23(2), 381-395.

Sharma P., Chrisman J., Chua J. (1997), Strategic Management of the Family Business: Past Research and Future Challenges, "Family Business Review", 10(1), 1-35.

Simon H. (1996), Hidden Champions, Boston, Harvard Business School Press.

Sullivan D. (1994), Measuring the Degree of Internationalization of a Firm, "Journal of International Business Studies", 25(2), 325-350.

Sun W., Stacy A., Ma H., Chou C-P. (2007), A SAS Macro to Calculate Standardized Cronbach's alpha using Upper Bound phi Coefficient for Dichotomous Items, "Behav Res Methods", 39(1), 71-81. 
Tagiuri R., Davis J. (1992), On the Goals of Successful Family Companies, "Family Business Review", 5(1), 43-62.

Tallman S., Fladmoe-Lindquist K. (1994), A Resource-Based Model of the Multinational Firm, Paper presented at the Strategic Management Society Conference, Paris.

Thomas J., Graves C. (2005), Internationalization of the Family Firm: The contribution of an Entrepreneurial Orientation, "Journal of Business and Entrepreneurship", 17(2), 91-113.

Tsao C.W., Chen S.J., Lin C.S., Hyde W. (2009), Founding-family ownership and firm performance: The role of high-performance work systems, "Family Business Review", 22(4), 319-332.

WANG Y. (2010), Correlates of Family Business Internationalisation. Paper presented at the IFERA Conference, Lancaster.

Welch L., Luostarinen R. (1988), Internationalization : Evolution of a Concept, "Journal of General Management", 14(2), 36-64.

Xiao J., Alhabeeb M., Hong G-S., Haynes G. (2001), Attitude Toward Risk and Risk-taking Behaviour of Business-owning families, 'The Journal of Consumer Affairs', 35(2), 307-226.

Yip G.S., Biscarri J.G., Monti J.A. (2000), The role of the internationalization process in the performance of newly internationalizing firms, "Journal of International Marketing", 8(3), 10-35.

Zahra S.A. (2003), International Expansion of US Manufacturing Family Businesses: The Effect of Ownership and Involvement, "Journal of Business Venturing”, 18(4), 495-512.

Zahra S.A. (2005), Entrepreneurial Risk Taking in Family Firms, "Family Business Review", 18(1), 23-40. 